Proceedings of the International Conference in Dubrovnik, 15-16 October 2015

\title{
STRAIN BEHAVIOUR OF ULTRA-HIGH-STRENGTH CONCRETE UNDER THE ELEVATED TEMPERATURE AND 0.25F
}

\author{
Gyu Yong Kimª, Young Wook Lee ${ }^{\mathrm{a}}$, Nenad Gucunski ${ }^{\mathrm{b}}$, Gyeong Cheol Choe ${ }^{\mathrm{a}}$, Min Ho Yoon ${ }^{\mathrm{a}}$ \\ a Department of Architecture Engineering, Chungnam National University, 99 Daehak-ro Yuseong-gu, South Korea \\ b Department of Civil and Environmental Engineering, Rutgers University, Picataway, NJ 008855-0909, USA
}

\begin{abstract}
The high-temperature creep of Ultra-High-Strength Concrete (UHSC) has been investigated in this study. The purpose of this study is to evaluated total strain and high-temperature creep at elevated temperatures under loading condition of UHSC. To evaluate the strain behaviour of UHSC at elevated temperatures, $\phi 100 \mathrm{~mm} \times 200 \mathrm{~mm}$ cylindrical specimens of UHSC with compressive strengths of 80,130 and $180 \mathrm{MPa}$ concrete were heated to $700{ }^{\circ} \mathrm{C}$ at a rate of $1{ }^{\circ} \mathrm{C} / \mathrm{min}$. The total strain and high-temperature-creep were measured under the loading condition of 0.25 of the compressive strength at room temperature. As results, Total strain of UHSC increased showing shrinkage with increasing compressive strength. The high-temperature creep of UHSC increased with the temperature and higher level of compressive strength showed bigger high-temperature creep.
\end{abstract}

Keywords: ultra-high-strength concrete, total strain, high-temperature creep, loading condition

\section{INTRODUCTION}

Since the applications of high-rise building structures have been increased, ultra-high-strength concrete (UHSC) is coming into use. Recently, UHSC that can be cast-in-place and cured at ambient temperatures to develop a compressive strength that exceeds $80 \mathrm{MPa}$ has been developed, and research on its practical applications is in progress (Yamamoto K et al., 2012). Many previous studies have shown that the inside of high-strength-concrete (UHSC) becomes denser at low water/cement ratios, and they show an even greater degradation in mechanical performance compared to normal-strength concrete (NSC) at elevated temperatures (Kim et al., 2009), (Schneider et al. 2007).

In the event of a fire, when the creep strain progresses upon the remaining resistance of the main structural members, the building structure may become irregular. Previous studies have shown that the high-temperature-creep of a concrete structure under fire conditions for 120-180 min is similar to the creep that occurs over 20-30 years under normal conditions (Wu. B et al. 2010). Thus, it can significantly influence the performance of the structure. For UHSC, which is used in skyscrapers, research needs to be conducted on shrinkage that occurs under loading condition at elevated temperature.

In this study, therefore, in order to evaluate the high-temperature-creep of UHSC, concrete specimens with compressive strengths of 80,130 , and $180 \mathrm{MPa}$ were subjected to a wide range of temperatures from room temperature to $700{ }^{\circ} \mathrm{C}$ under loading condition. Then, total strain, hightemperature-creep at elevated temperature under loading condition were evaluated.

\section{EXPERIMENT PLAN AND METHOD}

\subsection{Experiment plan}

In this study, an experiment was performed to evaluate the thermal strain behaviour and strength degradation of HSC with compressive strengths of 80, 130, and $180 \mathrm{MPa}$. Table 1 outlines the experimental plans. Two different loading conditions of $0 \mathrm{fcu}, 0.25 \mathrm{fcu}$ were used, and the target heating temperature conditions were set to $100,200,300,500$, and $700{ }^{\circ} \mathrm{C}$. 
Table 1 Experimental outline

\begin{tabular}{|c|c|c|c|c|}
\hline \multicolumn{4}{|c|}{ Experiment factor } & \multirow[b]{2}{*}{ Test item } \\
\hline $\begin{array}{c}\mathrm{F}_{\mathrm{ck}} \\
(\mathrm{MPa})\end{array}$ & $\mathrm{W} / \mathrm{B}^{1)}$ & $\begin{array}{l}\text { Restraining load } \\
\text { Rate }\left(f_{\mathrm{cu}}\right)\end{array}$ & $\begin{array}{c}\text { Temperature } \\
\left({ }^{\circ} \mathrm{C}\right)\end{array}$ & \\
\hline 80 & 0.20 & \multirow{3}{*}{$\begin{array}{l}0.00^{2)} \\
0.25^{3)}\end{array}$} & \multirow{3}{*}{$\begin{array}{c}100,200 \\
300,500 \\
700\end{array}$} & \multirow{3}{*}{$\begin{array}{l}\text { Total strain } \\
\text { High-temperature-creep }\end{array}$} \\
\hline 130 & 0.145 & & & \\
\hline 180 & 0.125 & & & \\
\hline
\end{tabular}

1) W/B : water-to-binder ratio, ${ }^{2)}$ unstressed, ${ }^{3)}$ stressed

The evaluated parameters were the high-temperature compressive strength, thermal expansion, total strain, high-temperature-creep, and transient creep.

\subsection{Materials}

In this study, cement (C), fly ash (FA), blast furnace slag (BFS), silica fume (SF) and anhydrous gypsum (Gy) were used as binders. Table 2 lists their chemical compositions and physical properties.

UHSC is frequently used for the structural members of skyscrapers and it requires an adequate pump pressure feed and decent workability. Therefore, in this study, crushed granite gravel with a specific weight of 2.70 , water absorption rate of $0.9 \%$, and maximum size of $13 \mathrm{~mm}$ was used as the coarse aggregate. Sea sand with a specific weight of 2.65 and water absorption rate of $1.00 \%$ was used as the fine aggregate.

\subsection{Concrete Mix and Production of Specimens}

Table 4 presents the mix proportions for UHSC used in this study. To reach compressive strengths of 80,130 , and $180 \mathrm{MPa}, \mathrm{W} / \mathrm{B}$ was set to $20.0 \%, 14.5 \%$, and $12.5 \%$, respectively. For the $80 \mathrm{MPa}$ concrete, cement (C), silica fume (SF), and fly ash (FA) were used as binders. For the 130 and 180 MPa concrete, C, blast furnace slag (BFS), SF, and anhydrous gypsum (AG) were used.

For the $80 \mathrm{MPa}$ concrete, the fine aggregate ratio was fixed at $43 \%$. For the 130 and $180 \mathrm{MPa}$ concrete, it was set to $35 \%$. The unit weight of water was fixed to $150 \mathrm{~kg} / \mathrm{m}^{3}$. Each specimen was produced by using a steel mould with dimensions of $\phi 100 \times 200 \mathrm{~mm}$. The mould was removed after $24 \mathrm{~h}$ of casting. Standard curing was then carried out at a temperature of $20 \pm 2{ }^{\circ} \mathrm{C}$.

Table 2 Chemical composition of used binders

\begin{tabular}{|c|c|c|c|c|c|}
\hline $\begin{array}{c}\text { Materials } \\
\text { Chemical composition (\%) }\end{array}$ & $\mathrm{OPC}^{1)}$ & $\mathrm{FA}^{2)}$ & $\mathrm{BFS}^{3)}$ & $\mathrm{SF}^{4)}$ & $\mathrm{AG}^{5)}$ \\
\hline $\mathrm{SIO}_{2}$ & 21.65 & 22.09 & 32.75 & 95.30 & 0.73 \\
\hline $\mathrm{AL}_{2} \mathrm{O}_{3}$ & 5.41 & 5.24 & 13.78 & 0.06 & 0.17 \\
\hline $\mathrm{Fe}_{2} \mathrm{O}_{3}$ & 3.24 & 3.52 & 0.42 & 0.02 & 0.16 \\
\hline $\mathrm{CaO}$ & 63.37 & 63.57 & 43.51 & 0.16 & 41.57 \\
\hline $\mathrm{MgO}$ & 2.28 & 2.18 & 3.8 & 0.3 & - \\
\hline $\mathrm{SO}_{3}$ & 2.04 & 2.03 & 5.23 & - & 55.5 \\
\hline $\mathrm{K}_{2} \mathrm{O}$ & 1.04 & 0.95 & 0.49 & 0.31 & 0.03 \\
\hline Loss on ignition $(\%)$ & 0.97 & 3.99 & - & - & - \\
\hline Density $\left(\mathrm{g} / \mathrm{cm}^{3}\right)$ & 3.15 & 2.2 & 2.90 & 2.5 & 2.5 \\
\hline Specific surface $\left(\mathrm{cm}^{2} / \mathrm{g}\right)$ & 3200 & 3000 & 6000 & 20105 & 3550 \\
\hline
\end{tabular}

1) OPC: ordinary Portland cement, ${ }^{2)}$ FA: fly ash, ${ }^{3)} \mathrm{BFS}$ : blast furnace slag, ${ }^{4)} \mathrm{SF}$ : silica fume, 5) AG: anhydrous gypsum 
Table 4 Mix proportions of UHSC

\begin{tabular}{|c|c|c|c|c|c|c|c|c|c|c|c|c|}
\hline \multirow{2}{*}{$\begin{array}{c}\mathrm{f}_{\mathrm{ck}} \\
(\mathrm{MPa})\end{array}$} & \multirow{2}{*}{$\begin{array}{l}\text { W/B } \\
(\%)\end{array}$} & \multirow{2}{*}{$\begin{array}{c}\text { Slump } \\
\text { flow } \\
(\mathrm{mm})\end{array}$} & \multirow{2}{*}{$\begin{array}{l}\text { S/a } \\
(\%)\end{array}$} & \multirow{2}{*}{$\begin{array}{l}\text { Air } \\
(\%)\end{array}$} & \multicolumn{8}{|c|}{ Unit weight $\left(\mathrm{kg} / \mathrm{m}^{3}\right)$} \\
\hline & & & & & W & $\mathrm{C}$ & BFS & $\mathrm{SF}$ & FA & $\mathrm{AG}$ & $\mathrm{S}$ & $\mathrm{G}$ \\
\hline 80 & 20.0 & \multirow{3}{*}{$\begin{array}{c}750 \\
\pm \\
100\end{array}$} & 43.0 & \multirow{3}{*}{$2 \pm 1$} & \multirow{3}{*}{150} & 525 & 0 & 75 & 150 & 0 & 644 & 870 \\
\hline 130 & 14.5 & & 35.0 & & & 652 & 207 & 124 & 0 & 52 & 448 & 848 \\
\hline 180 & 12.5 & & 35.0 & & & 660 & 240 & 240 & 0 & 60 & 389 & 736 \\
\hline
\end{tabular}

Each specimen was cured in water for $7 \mathrm{~d}$ ays and then cured in a chamber of constant humidity $\left(60 \pm 5 \%\right.$ Relative Humidity) and temperature $\left(20 \pm 2{ }^{\circ} \mathrm{C}\right)$ for up to 300 days. Then, a heating test was performed.

\subsection{Testing Method}

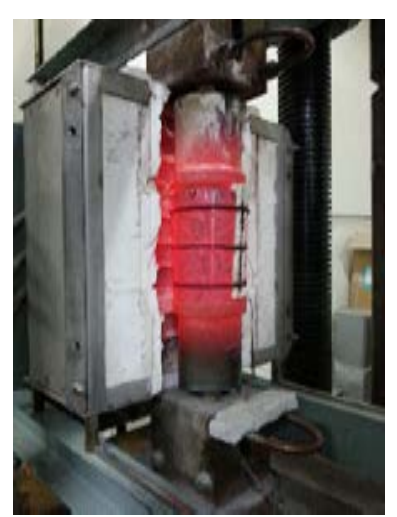

Fig. 1 Test equipment for heating and loading

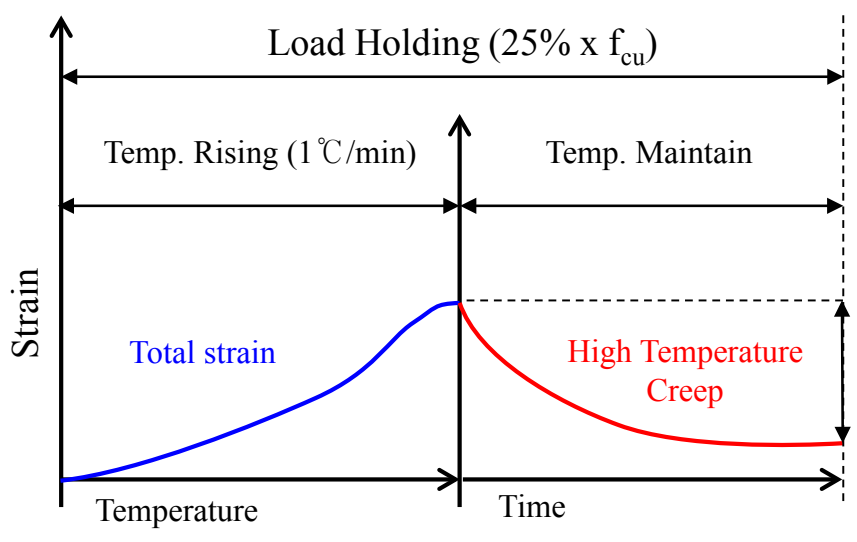

Fig. 2 Heating method of this study

The test equipment for heating and loading is shown in Fig. 1. For simultaneous loading and heating, an electric heating furnace was installed loading apparatus with a capacity of $2000 \mathrm{kN}$. Furthermore, the strain of the test specimens during heating was measured by transferring the strain to the displacement meters placed outside through a quartz tube of $\varnothing 100 \mathrm{~mm}$ in diameter in order to prevent damages from high temperature, which penetrated the centre of the upper and lower loading jigs.

To increase the temperature inside and outside of the test specimens to the same level, an indirect heating method was used in which heat was transferred to the test specimens by heating the upper and lower loading jigs. Furthermore, the heating rate was set at $1{ }^{\circ} \mathrm{C} / \mathrm{min}$ to maintain the temperature difference within $5{ }^{\circ} \mathrm{C}$ between the inside and outside of the test specimens (RILEM TC 129-MHT. 2007).

Fig. 2 shows the heating method of this study. The total strain was measured under heating and loading conditions, at a load of $25 \%$ of the compressive strength at room temperature. The hightemperature-creep was measured for $300 \mathrm{~min}$ after the target temperature was reached, at the conditions of the heating temperatures and load of $25 \%$ of the compressive strength at room temperature (RILEM TC 129-MHT. 2007).

\section{TEST RESULTS AND CONSIDERATIONS}

\subsection{Total Strain}

Fig. 3 shows the total strain of UHSC depending on the temperature. The total strain was when a load and heat were applied at the same time. According to existing researches, concrete shows expansion behaviour when it is heated without loading condition. However, the total strain of UHSC which was obtained by elevated temperature with loading condition showed shrinkage 


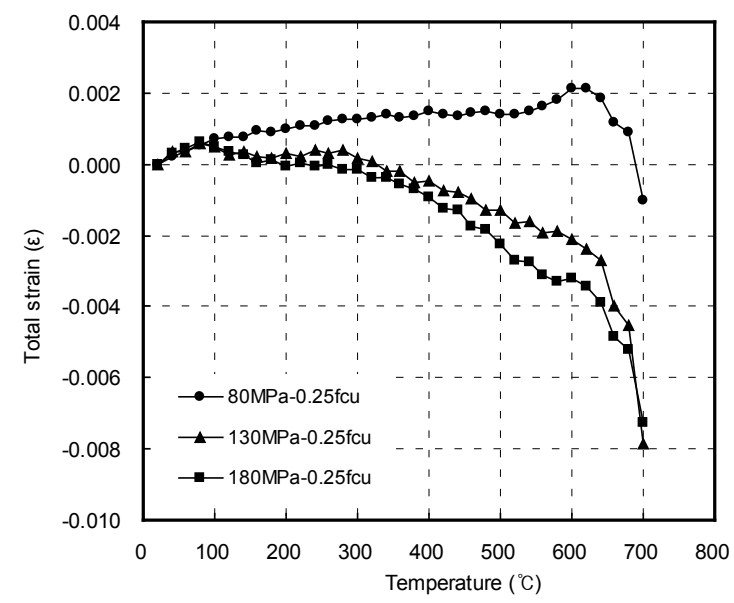

Fig. 3 Total strain of UHSC at elevated temperature under loading

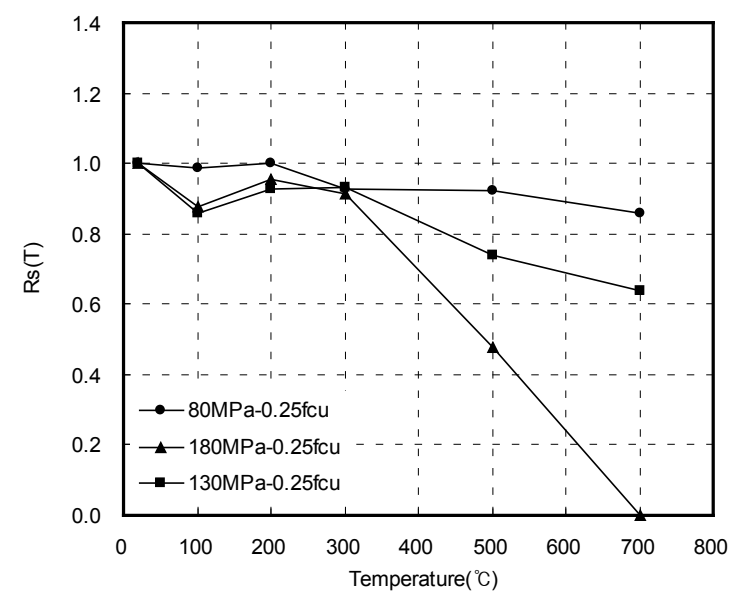

Fig. 4 Strength ratio of $0.25 f_{\text {cu }}$ load/strength at each temperature

behaviour in the end. The reason for the reduction of the thermal expansion was the offsetting effects caused by the load.

For the $80 \mathrm{MPa}$ concrete, until $600^{\circ} \mathrm{C}$, the total strain has been maintained at 0.001 strain. Then, the specimen shrunk at temperatures above $600{ }^{\circ} \mathrm{C}$.

For the 130 and $180 \mathrm{MPa}$ concrete, the thermal expansion has been shown up to $100{ }^{\circ} \mathrm{C}$. Then the shrinkage strain gradually appeared above $300^{\circ} \mathrm{C}$. When the temperature was above $600{ }^{\circ} \mathrm{C}$, which produces a change in the concrete state, a shrinkage strain occurred abruptly. The total strain were -0.0072 and -0.0089 at $700{ }^{\circ} \mathrm{C}$, respectively.

The total strain tended to decrease at high temperatures as W/B decreased. Fig. 4 shows the initial load corresponding to $25 \%$ of the compressive strength at room temperature along with the $\operatorname{Rs}(\mathrm{T})$ ratio, which is the compressive strength at each corresponding temperature $\left(f_{c, T}\right)$. The compressive strength have been decreased with increasing temperature and decreasing W/B. Therefore, even though a load corresponding to $25 \%$ of the compressive strength at room temperature was applied equally, the rate of decrease in the compressive strength greatly increased for lower W/B as the temperature increased. The greater load rates at elevated temperatures were assumed to result in a significant shrinkage of the total strain for lower W/B.

\subsection{High-Temperature-Creep}

Fig. 5 shows $5 \mathrm{~h}$ of high-temperature creep for the UHSC concrete as evaluated according to the high-temperature-creep test method [19]. The figure 5(c) shows the high-temperature-creep at $700{ }^{\circ} \mathrm{C}$ for the $180 \mathrm{MPa}$ concrete; compressive fracture occurred from the load $(\sigma)$ during the test. 


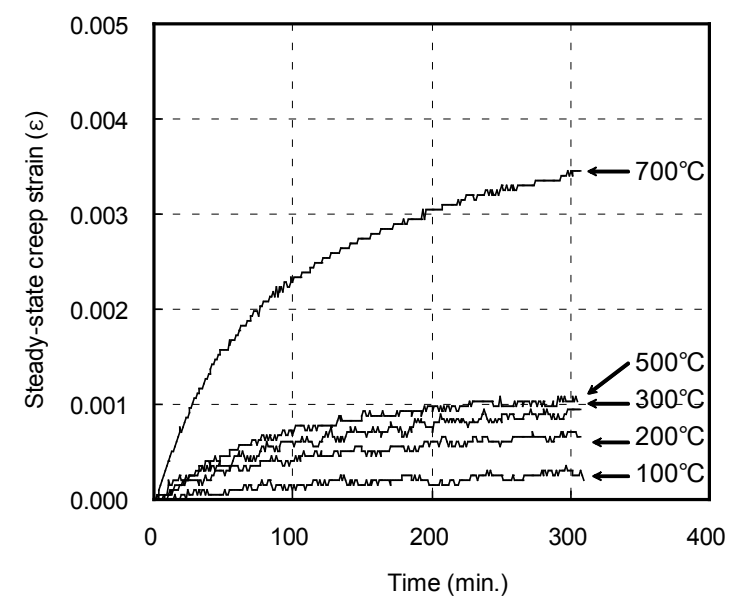

(a) $80 \mathrm{MPa}$

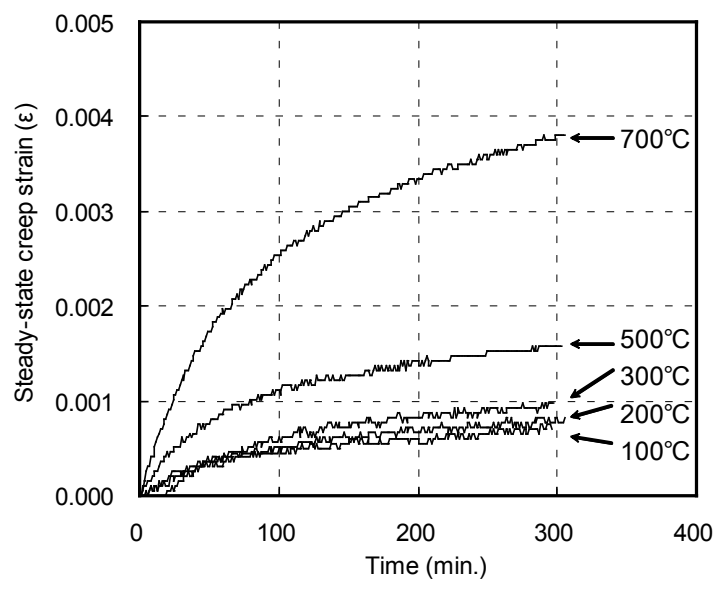

(b) $130 \mathrm{MPa}$

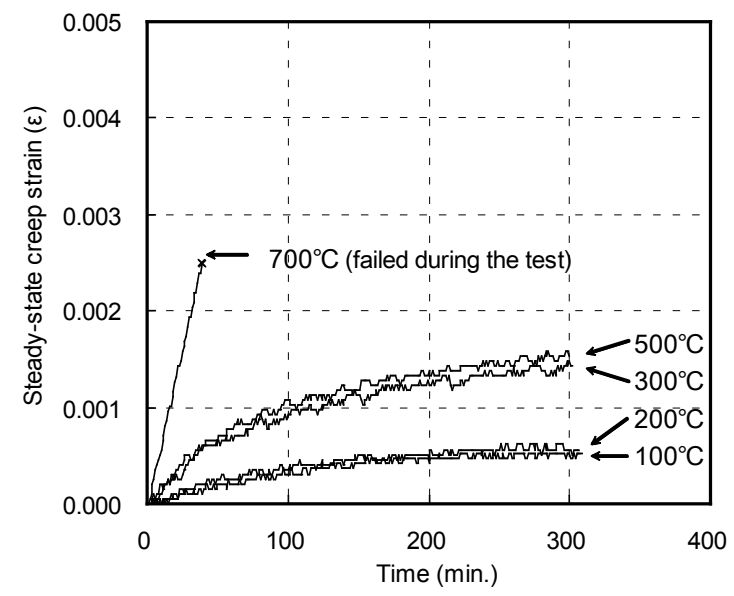

(c) $180 \mathrm{MPa}$

Fig. 5 Total strain of UHSC at elevated temperature under loading

The high-temperature-creep of HSC increased with the temperature regardless of W/B. Very highspeed high-temperature-creep behaviour occurred in the first 50 min for every specimen.

When the temperature was below $500{ }^{\circ} \mathrm{C}$, about $80 \%$ of the high-temperature-creep over $300 \mathrm{~min}$ was caused by the shrinkage in the initial $100 \mathrm{~min}$. The specimen then showed a constant strain value. Above $500{ }^{\circ} \mathrm{C}$, over $60 \%$ of the high-temperature-creep of $300 \mathrm{~min}$ was caused by creep shrinkage in the initial $100 \mathrm{~min}$. After that, the shrinkage rate decreased, but a significant amount of creep continued to occur.

A small high-temperature-creep of approximately 0.002 occurred at temperatures up to $500{ }^{\circ} \mathrm{C}$ during the $5 \mathrm{~h}$ of the creep test. However, there was a clear difference in high-temperature-creep at 
$700{ }^{\circ} \mathrm{C}$ (see Fig. 4(a), (b)). The high-temperature-creep was about three times larger at $700{ }^{\circ} \mathrm{C}$ compared to below $500{ }^{\circ} \mathrm{C}$. The strain behaviour of the high-temperature-creep greatly increased at lower W/B ratios. This is because creep is linearly proportional to the axial ratio $\left(\sigma / f_{c, T}\right)$; thus, it helps cause the total strain, as noted previously (Fig.4).

\section{CONCLUSIONS}

The results with regard to the experiment in this study are as follows

- Since the compressive strength have been decreased with increasing temperature and decreasing W/B, it was clearly shown that the shrinkage of UHSC increases as W/B decreases in total strain. Also, it was considered that the reason why 130 and $180 \mathrm{MPa}$ concrete were not fractured even with a significant total strain of -0.006 at $700{ }^{\circ} \mathrm{C}$ during the application of a $0.25 \mathrm{f}_{\mathrm{cu}}$ load was resisting force has been occurred gradually as crack had been adjusted by load.

- The resisting force of HSC to withstand a certain amount of load rapidly deteriorated when it was heated to high temperatures. This is because of the reduced amount of aggregate and increased binder content which make extremely density matrix in the concrete for higher compressive strength development. In other words, resistance properties of concrete to high temperature is degraded when there are more binders with ah igh rate of thermal decomposition and shrinkage. This phenomenon was particularly evident as the compressive strength increased.

- The high-temperature-creep of UHSC increased with the temperature in every specimen. Also, it was shown that the high-temperature-creep sharply occurred at initial time and showed much higher shrinkage at $700{ }^{\circ} \mathrm{C}$ even if the constant load level has been kept. Therefore, not only the total strain which occurs under heating and loading condition but also hightemperature-creep which occurs under constant high temperature and loading condition needs to be considered for design of UHSC.

- HSC has the great advantage of providing structural stability to a building because of its high material strength. However, the risk of fire needs to be considered because its resistance sharply decreases when exposed to high temperatures. While this is beyond the scope of this research, the thermal expansion of the material also needs to be considered by evaluating the material properties and heat capacity of the UHSC components under applied heat and load conditions.

\section{ACKNOWLEDGMENTS}

This study was supported by research fund of Chungnam National University in 2014.

\section{REFERENCES}

Kim, G. Y., Kim, Y. S., and Lee, T. G. 2009. Mechanical Properties of High-Strength Concrete Subjected to High Temperature by Stressed Test, Transactions of Nonferrous Metals Society of China, Vol. 19, 2009, p. 128-133.

RILEM TC 129-MHT, 2000. Test Methods for Mechanical Properties of Concrete at High Temperatures: Part 8 Steady-State Creep and Creep Recovery for Service and Accident Conditions, Materials and Structures, Vol. 33, 2000, p. 6-13.

Schneider, U. 2007. Recommendation of RILEM TC 200-HTC: Mechanical Concrete Properties at High Temperatures-Modelling and Application. Part 11: Relaxation, Materials and Structures, Vol. 40, p. 449-458.

Wu, B., Lam, S. S., Liu, Q., Chung, Y. M., Ho, L. F. Y. 2010. Creep Behavior of High-Strength Concrete with Polypropylene Fibers at Elevated Temperatures, ACI Materials Journal, Vol. 107, No. 2, p. 176-184.

Yamamoto K, Nakajima T, Watanabe S, Shimizu Y. 2011. High-rise Building Operations using Ultra High Strength Concrete with a Design Strength of 200 MPa, Concrete journal, Vol. 49, p. 37-42. 